\title{
Oświadczenie Ministerstwa Spraw Zagranicznych Republiki Azerbejdżanu z okazji 8 listopada - Dnia Zwycięstwa w Republice Azerbejdżanu
} Statement by the Ministry of Foreign Affairs of the Republic of Azerbaijan on November 8 Victory Day in the Republic of Azerbaijan Заявление Министерства иностранных дел Азербайджанской Республики по случаю 8 ноября Дня Победы в Азербайджанской Республике

Dnia 8 listopada 2021 roku Republika Azerbejdżanu obchodzi Dzień Zwycięstwa, który stał się świętem potęgi narodu azerbejdżańskiego i naszej narodowej dumy i ma wyjątkowe znaczenie dla prestiżu i przyszłego rozwoju naszego państwa.

W odpowiedzi na prowokację Armenii i dalszą agresję militarną Azerbejdżan w wyniku 44-dniowej Wojny Ojczyźnianej, która rozpoczęła się 27 września 2020 r., wyzwolił swoje ziemie spod okupacji; tym samym, zgodnie z odpowiednimi rezolucjami Rady Bezpieczeństwa ONZ, a także wymogami licznych decyzji i rezolucji innych organizacji międzynarodowych, zapewniono integralność terytorialną Azerbejdżanu w jego granicach międzynarodowych, przywrócono prawo około milionowi azerbejdżańskich przesiedleńców do powrotu i zamieszkania w swoich rodzinnych domach.

W wyniku 44-dniowej operacji wojskowej, pod dowództwem Naczelnego dowódcy sił zbrojnych, Prezydenta Ilhama Alijewa, niepokonana armia azerbejdżańska uwolniła spod okupacji ponad 300 osad mieszkalnych, w tym miasta Dżabrayil, Fizuli, Zangilan, Gubadli oraz miasto Szusza, które 
zajmuje szczególne miejsce w historii i kulturze narodu azerbejdżańskiego. Trójstronne porozumienie podpisane 10 listopada 2020 r. przez przywódców Azerbejdżanu, Rosji i Armenii zakończyło operacje wojskowe, a Armenia, uznając swoją porażkę, wycofała siły zbrojne z rejonów Kalbadżar, Agdam i Laczyn. Tym samym konflikt został rozwiązany w sposób militarno-polityczny.

Powojenny Azerbejdżan stoi przed ważnym zadaniem odbudowy i rekonstrukcji wyzwolonych terytoriów, oczyszczenia tych obszarów z min. Sednem tej pracy jest zapewnienie bezpiecznego i godnego powrotu azerbejdżańskich uchodźców wewnętrznych, których podstawowe prawa były łamane od trzech dekad, do ich domów. W tym procesie, który wymaga dużo czasu, środków finansowych i poważnych wysiłków, Azerbejdżan nie jest sam. Zaprzyjaźnione i partnerskie kraje biorą udział w procesie rewitalizacji wyzwolonych terenów. W najbliższych latach będziemy świadkami powrotu przesiedleńców do swoich domów.

Azerbejdżan podjął odpowiednie kroki, które będą kontynuowane na kolejnym etapie, w celu przeprowadzenia śledztwa w sprawie nielegalnych działań popełnionych przez Armenię w ramach trwającej prawie 30 lat polityki agresji, naruszeń prawa międzynarodowego, zbrodni wojennych, w tym urbicydów, kulturocydów i ekocydów oraz pociągnięcia do odpowiedzialności przed międzynarodowym wymiarem sprawiedliwości osób bezpośrednio odpowiedzialnych za te naruszenia. Ukaranie sprawców jest istotne pod względem zapewnienia sprawiedliwości i zapobiegnięcia powtórzeniu się tych przypadków w przyszłości.

Zapewnienie trwałego pokoju, rozwoju i postępu jest podstawą przyszłej strategii Azerbejdżanu. Eliminując czynnik okupacji swoich terytoriów, Azerbejdżan jest gotowy do normalizacji stosunków z Armenią w oparciu o ścisłe przestrzeganie zasad prawa międzynarodowego, w szczególności zasad suwerenności, integralności terytorialnej i nienaruszalności granic międzynarodowych. Dla zapewnienia przyszłego pokoju i bezpieczeństwa w regionie ważne jest pełne na tym etapie wdrożenie trójstronnych porozumień. Pod tym względem Azerbejdżan oczekuje na odpowiednią wzajemną reakcję ze strony Armenii.

Wraz z zakończeniem konfliktu w regionie Kaukazu Południowego pojawiły się nowe realia, które każdy powinien zaakceptować. Armenia musi 
wybierać między współpracą regionalną a nielegalnymi i nieuzasadnionymi roszczeniami terytorialnymi wobec sąsiadów. Społeczność międzynarodowa musi odegrać w tym względzie pozytywną rolę i wezwać Armenię do uświadomienia sobie, że nie ma alternatywy dla pokoju. Próby bezpośredniego lub pośredniego wspierania rewanżyzmu i jego uzbrojenia w Armenii muszą zostać powstrzymane.

8 listopada - Dzień Zwycięstwa - to święto międzynarodowego prawa i sprawiedliwości, stanowiące chwalebną kartę w historii narodu Azerbejdżanu. W tym ważnym dniu oddajemy hołd z głębokim szacunkiem pamięci wszystkich poległych, którzy oddali życie za niepodległość, suwerenność i integralność Azerbejdżanu. 